\title{
Phytochemical Profile and Antidepressant Effect of Ormosia henryi Prain Leaf Ethanol Extract
}

\author{
Ying Lu ${ }^{1,2, \dagger}$, Shihao Zhu ${ }^{1, \dagger}$, Yingjie He ${ }^{1,2, * \mathbb{D}}$, Changfu Peng ${ }^{3}$, Zhi Wang ${ }^{4}$ and Qi Tang ${ }^{1,2, *}$ \\ 1 Hunan Key Laboratory of Traditional Chinese Veterinary Medicine, Hunan Agricultural University, \\ Changsha 410128, China \\ 2 National Research Center of Engineering Technology for Utilization of Functional Ingredients from \\ Botanicals, Hunan Agricultural University, Changsha 410128, China \\ 3 Hunan Linuo Biological Pharmaceutical Co. LTD, Guiyang 424400, China \\ 4 College of Pharmacy, Hunan University of Chinese Medicine, Changsha 410208, China \\ * Correspondence: yingjiehe272@163.com (Y.H.); tangqi@hunau.edu.cn (Q.T.) \\ + These authors contributed equally to this work.
}

Received: 4 June 2019; Accepted: 9 July 2019; Published: 10 July 2019

\begin{abstract}
The Ormosia henryi Prain leaf (OHPL) is a new bioactive resource with potential antidepressant activity, but few reports have confirmed its chemical composition or antidepressant effect. To investigate the phytochemical profile of OHPL ethanol extract (OHPLE), six flavone $\mathrm{C}$-glycosides and two flavone $\mathrm{O}$-glycosides were purified by high-speed counter-current chromatography combined with preparative high-performance liquid chromatography (HSCCC-prep-HPLC). The eight isolated compounds were identified by NMR and MS. Forty-six flavonoids, including flavones, flavone $C$-glycosides, flavone $O$-glycosides, isoflavones, isoflavone $O$-glycosides, prenylflavones and polymethoxyflavones were definitively or tentatively identified from OHPLE using ultra-performance liquid chromatography/ electrospray ionization quadrupole time-of-flight mass spectrometry (UPLC-ESI-QTOF-MS/MS) on the basis of fragment ions that are characteristic of these isolated compounds. The results of the antidepressant assay suggest that OHPLE significantly improved depression-related behaviors of chronic unpredictable mild stress (CUMS) mice. The observed changes in these mice after OHPLE treatment were an increased sucrose preference index, reduced feeding latency, prolonged tail suspension time, and upregulated expression of brain-derived neurotrophic factor (BDNF). The details of the phytochemicals and the antidepressant effect of OHPLE are reported here for the first time. This study indicates that the OHPL, enriched in flavone $C$-glycosides, is a new resource that might be potentially applied in the field of nutraceuticals (or functional additives) with depression-regulating functions.
\end{abstract}

Keywords: HSCCC-prep-HPLC; UPLC-ESI-QTOF-MS/MS; flavone C-glycosides; CUMS mice; antidepressant effect; Ormosia henryi Prain leaf

\section{Introduction}

Depression-like diseases are complicated mental disorders characterized by a series of clinical symptoms, such as decreased interest, mood, and pleasure; and increased anxiety, sadness, stress, and anorexia [1-3]. Depression is treated with diverse clinical drugs, which are effective to a certain extent. Many antidepressant drug families, such as selective serotonin reuptake inhibitors, serotonin-norepinephrine reuptake inhibitors, tricyclic antidepressants, and monoamine oxidase inhibitors, work by enhancing the levels of neurotransmitters [4,5]. However, these synthetic antidepressants produce a lot of adverse effects, including serotonin syndrome, which is responsible for psychiatric disorders that induce behaviors such as irascibility, instability, distress, 
insomnia, and confusion [6,7]. Additional side effects include hypomania, hypertensive crisis, spontaneous abortion, and diminished libido [8-10]. Therefore, natural bioactive compounds with antidepressant activities and fewer side effects are needed as alternative depression treatments. Current studies have shown that many natural compounds or traditional herbal components can be used as clinical drugs or functional food sources for the treatment of depressive disorders. Natural plant sources produce secondary metabolites, such as flavonoids, coumarins, alkaloids, terpenoids, saponins, and polysaccharides, which have been proved to possess antidepressant activities [11]. Therefore, screening for low-toxicity, potent antidepressant compounds or components from natural plant sources is important for the development of novel nutraceuticals or health foods with depression-regulating functions. Such compounds include flavonoids, which have broad application value because of their antidepressant effects, low toxicities, and safety [8].

Ormosia henryi Prain (OHP), which belongs to the genus Ormosia (family Leguminosae), is a perennial green tree that is widely distributed in southern China. OPH roots, leaves, and stem bark have been applied as folk medicine to alleviate swallowing disorders, pain, and inflammation [12]. Clinical applications of traditional folk medicine have shown that OPH leaves possess a refreshing, invigorating, and antidepressant effect, suggesting that this plant has the potential for treating depression [13]. However, few studies have investigated the phytochemicals or pharmacological activities of OHP. Feng et al. conducted such a study, in which the constituents and the anti-inflammatory effect of OHP roots were assessed [12]. As a potential renewable resource, the phytochemical composition and antidepressant activity of the OHP leaf (OHPL) should be further studied.

Therefore, the main objectives of this study are to investigate the phytochemical profile and antidepressant effect of OHPL. To this end, OHPL was extracted by ethanol and eluted with macroporous resin (70\% ethanol) to obtain OHPL ethanol extract (OHPLE). Eight flavonoids, including six flavone $\mathrm{C}$-glycosides and two flavone $\mathrm{O}$-glycosides, were separated and purified by combining high-speed counter-current chromatography and preparative high-performance liquid chromatography (HSCCC-prep-HPLC). The purified compounds were then characterized by NMR and MS. The characteristic fragment ions of the purified $C$-flavones and $O$-flavones were selected by ultra-performance liquid chromatography/electrospray ionization quadrupole time-of-flight mass spectrometry (UPLC-ESI-QTOF-MS/MS) to characterize or tentatively identify other homologous compounds in OHPLE, and the phytochemical constituents in OHPLE were systematically analyzed. Quantitative analysis was also carried out by using HPLC to measure the flavonoid compounds, and the results suggest that flavonoids are the dominant bioactive components of OHPLE. The antidepressant effect of OHPLE was evaluated by performing behavioral tests on chronic unpredictable mild stress (CUMS) mice. The sucrose preference test (SPT), ingestion latency test (ILT), and tail suspension test (TST) were conducted to identify changes in behavior after OHPLE treatment. Brain-derived neurotrophic factor (BDNF) expression in the hippocampus of test mice was also investigated. This study can be used as a reference for the development of OHPL as a new potential resource for antidepressant-related applications or a health functional food to decrease the risk of developing depression-like diseases.

\section{Results}

\subsection{Isolation and Identification of Compounds $\boldsymbol{a}-\boldsymbol{h}$}

The advantages of using HSCCC to isolate compounds from a complex mixture include high recovery, low consumption of solvents, and the non-denaturing and reversible adsorption of target compounds [14]. Consequently, HSCCC has been frequently employed as an efficient separation and preparative tool to isolate natural compounds from complicated mixtures of components. The key factors of HSCCC were successfully improved for the separation of the targets in this study, as detailed in Section 4.2. A combination of separation procedures using AB-8 macroporous resin and a prep-HPLC apparatus resulted in the efficient purification of eight compounds from OHPL (Figure 1). Six flavone 
C-glycosides and two flavone $\mathrm{O}$-glycosides were identified by ${ }^{1} \mathrm{H}$ - and ${ }^{13} \mathrm{C}$-NMR (Figure S1, Table S1) and MS. The ${ }^{1} \mathrm{H}$ - and ${ }^{13} \mathrm{C}-\mathrm{NMR}$ results are specified in Table $\mathrm{S} 1$ and the details are listed below.<smiles>[R]c1cc(-c2cc(=O)c3c(O)c([R])c(O)c([R3])c3o2)ccc1O</smiles>

a: luteolin 6- $C$-neohesperidoside; $\mathrm{R}_{1}=\mathrm{OH}, \mathrm{R}_{2}=$ neohesperidoside, $\mathrm{R}_{3}=\mathrm{H}$

b: luteolin 6- $C$-glucoside; $\mathrm{R}_{1}=\mathrm{OH}, \mathrm{R}_{2}=$ glucoside, $\mathrm{R}_{3}=\mathrm{H}$

c: luteolin 8-C-glucoside; $\mathrm{R}_{1}=\mathrm{OH}, \mathrm{R}_{2}=\mathrm{H}, \mathrm{R}_{3}=$ glucoside

d: apigenin 8-C-neohesperidoside; $\mathrm{R}_{1}=\mathrm{H}, \mathrm{R}_{2}=\mathrm{H}, \mathrm{R}_{3}=$ neohesperidoside

e: apigenin 6-C-neohesperidoside; $\mathrm{R}_{1}=\mathrm{H}, \mathrm{R}_{2}=$ neohesperidoside, $\mathrm{R}_{3}=\mathrm{H}$

f: apigenin $6-C$-glucoside; $\mathrm{R}_{1}=\mathrm{H}, \mathrm{R}_{2}=$ glucoside, $\mathrm{R}_{3}=\mathrm{H}$<smiles>[R]Oc1cc(O)c2c(=O)cc(-c3ccc(OC)c([R])c3)oc2c1</smiles>

g: diosmetin 7-O-rutinoside; $\mathrm{R}_{1}=\mathrm{OH}, \mathrm{R}_{2}=$ rutinoside h: acacetin 7-O-rutinoside; $\mathrm{R}_{1}=\mathrm{H}, \mathrm{R}_{2}=$ rutinoside

Figure 1. Structures of compounds $\boldsymbol{a}-\boldsymbol{h}$.

Compound a: Yellowish powder, UV absorption at 270 and $352 \mathrm{~nm}, \mathrm{~m} / \mathrm{z} 593.1515[\mathrm{M}-\mathrm{H}]^{-}$. Identified as luteolin 6-C-neohesperidoside (isoorientin-2"-O-rhamnoside) $[15,16]$.

Compound b: Yellowish powder, UV absorption at 270 and $350 \mathrm{~nm}, \mathrm{~m} / z 447.0931[\mathrm{M}-\mathrm{H}]^{-}$. Identified as luteolin 6-C-glucoside (isoorientin) [17].

Compound c: Yellow-green powder, UV absorption at 268 and $350 \mathrm{~nm}, \mathrm{~m} / \mathrm{z} 447.0931[\mathrm{M}-\mathrm{H}]^{-}$. Identified as luteolin 8-C-glucoside (orientin) [17,18].

Compound $d$ : Yellow-brown powder, UV absorption at 269 and $340 \mathrm{~nm}$, deprotonated ion at $\mathrm{m} / \mathrm{z}$ $577.1564[\mathrm{M}-\mathrm{H}]^{-}$. Identified as apigenin 8-C-neohesperidoside (vitexin-2"'-O-rhamnoside) [19].

Compound $e$ : Yellow-brown powder, $\mathrm{UV}$ absorption at 270 and $340 \mathrm{~nm}$, deprotonated ion at $\mathrm{m} / \mathrm{z}$ $577.1562[\mathrm{M}-\mathrm{H}]^{-}$. Identified as apigenin 6-C-neohesperidoside (isovitexin-2"'-O-rhamnoside) [20].

Compound $f$ : Light green powder, UV absorption at 270 and $338 \mathrm{~nm}$, deprotonated ion at $\mathrm{m} / \mathrm{z}$ $431.0985[\mathrm{M}-\mathrm{H}]^{-}$. Identified as apigenin 6-C-glucoside (isovitexin) [21,22].

Compound $\mathrm{g}$ : White powder, UV absorption at 266 and $348 \mathrm{~nm}, \mathrm{~m} / \mathrm{z} 607.1783[\mathrm{M}-\mathrm{H}]^{-}$. Identified as diosmetin 7-O-rutinoside (diosmin) [23].

Compound $\boldsymbol{h}$ : White powder, UV absorption at 269 and $332 \mathrm{~nm}, \mathrm{~m} / z 591.1880[\mathrm{M}-\mathrm{H}]^{-}$. Identified as acacetin 7-O-rutinoside (linarin) [24,25].

It is noteworthy that flavone $C$-diglycosides, such as luteolin 6-C-neohesperidoside, exhibited double NMR signals because the disaccharide substituent differs in spatial conformation, resulting in different structures [20]. Results suggest the presence of two conformers of flavone C-diglycosides.

\subsection{Phytochemical Investigation of OHPLE using UPLC-ESI-QTOF-MS/MS}

For the characterization of other homologous compounds, the eight compounds isolated from OHPLE were selected as reference standards to analyze their MS fragmentation patterns. The UPLC-UV chromatogram (340 nm) and UPLC-ESI-QTOF-MS/MS base peak ion chromatogram of OHPLE are shown in Figure 2. By careful deduction, 46 flavonoids (Table 1) were definitively or preliminarily characterized by comparing their precise molecular weights, retention times, ultraviolet spectra, splitting patterns, and fragment ions with those of the reference compounds or values in the literature. 

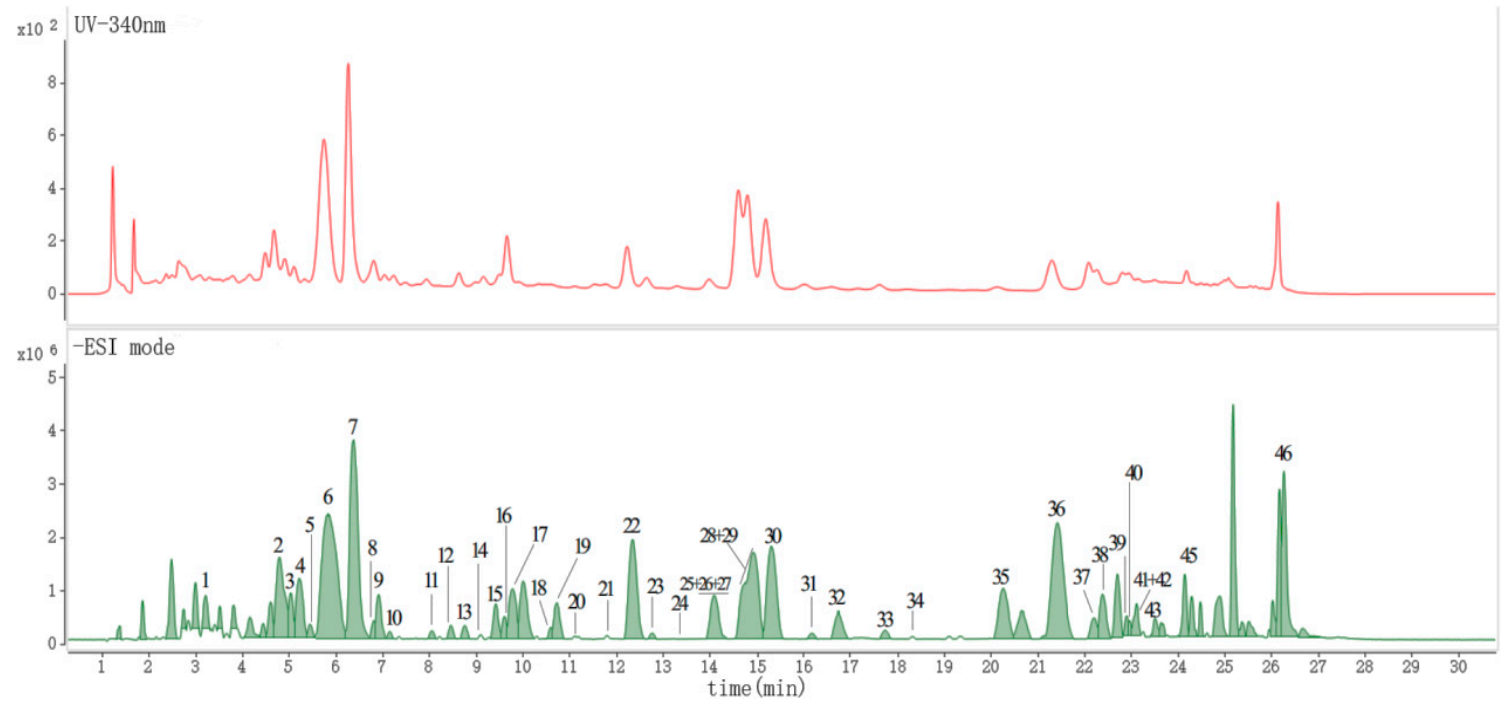

Figure 2. UPLC-UV chromatogram $(340 \mathrm{~nm})$ and UPLC-ESI-QTOF-MS/MS base peak chromatogram (BPC) in negative ESI mode of OHPLE.

In particular, we elaborate on the main components of flavone $C$-glycosides. In previous studies, flavone C-glycosides have usually been found at positions C-6 and/or C-8 [26], and this was also observed for OHPLE. Flavone $C$-glycosides were found to be the main components in OHPLE. The general nomenclature of the fragments is shown in Figure 3.

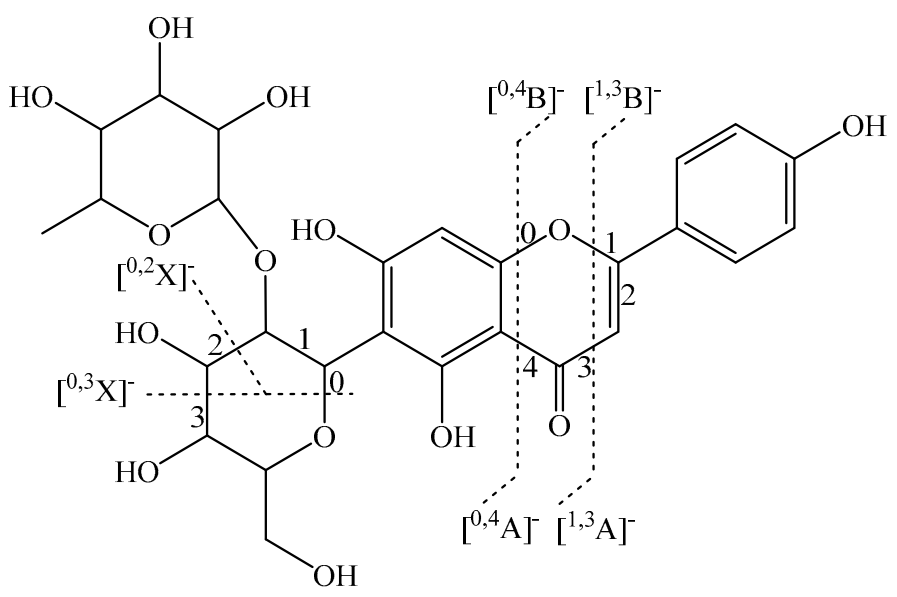

Figure 3. Nomenclature of fragments (apigenin 6-C-neohesperidoside is shown as an example).

The flavone $C$-monoglycoside isomers luteolin 6-C-glucoside $(\boldsymbol{b})$ and luteolin 8-C-glucoside (c) and the flavone $C$-diglycoside isomers apigenin 6-C-neohesperidoside $(e)$ and apigenin 8-C-neohesperidoside $(\boldsymbol{d})$ are shown in Figure 4 as examples of flavone $C$-glycosides to illustrate the typical fragmentation patterns found by UPLC-ESI-QTOF-MS/MS. 

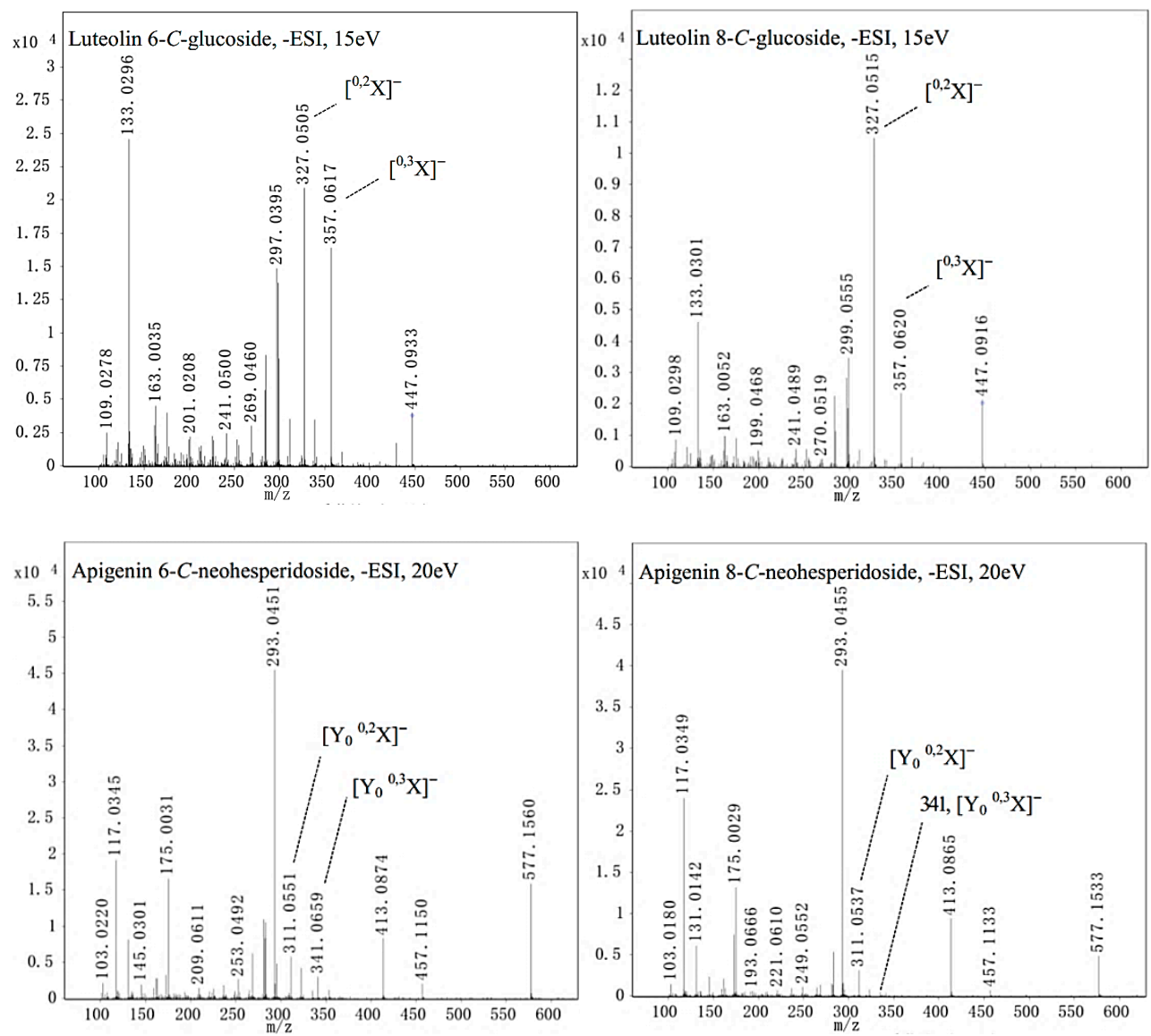

Figure 4. MS fragments of two pairs of $C$-flavone isomers.

Briefly, flavone $C$-diglycoside was first cleaved into an ion of flavone $C$-monoglycoside by the loss of a rhamnoside (Rha) $[\mathrm{M}-\mathrm{H}-146]^{-}$at low collision energy $(5 \mathrm{eV})$. From the loss of Rha, $\left.{ }^{0,3} \mathrm{X}\right]^{-}\left([\mathrm{M}-\mathrm{H}-146-90]^{-}\right)$and $\left[^{0,2} \mathrm{X}\right]^{-}\left([\mathrm{M}-\mathrm{H}-146-120]^{-}\right)$fractures were the dominant fragmentation pathways at increased energy $(20 \mathrm{eV})$. The relative abundance ratio of $\left[{ }^{0,3} \mathrm{X}\right]^{-}$and $\left[{ }^{0,2} \mathrm{X}\right]^{-}$was used as a critical index to discriminate between $C-6$ and $C-8$ glycosides. The compound was identified as a $C-6$ glycoside when $\left[^{0,3} \mathrm{X}\right]^{-} /\left[^{0,2} \mathrm{X}\right]^{-}$was greater than $1 / 2$. If $\left[{ }^{0,3} \mathrm{X}\right]^{-} /\left[^{0,2} \mathrm{X}\right]^{-}$was less than or close to $1 / 5$, the compound was designated as a $C-8$ glycoside. The main fragmentation pathways of flavone C-monoglycosides were $\left[^{0,3} \mathrm{X}\right]^{-}\left([\mathrm{M}-\mathrm{H}-90]^{-}\right)$and $\left[{ }^{0,2} \mathrm{X}\right]^{-}\left([\mathrm{M}-\mathrm{H}-120]^{-}\right)$cleavages, which followed the same pattern of flavone $C$-diglycoside cleavages. The other flavone $C$-glycosides isolated from OHPL exhibited results consistent with this pattern. Dehydration $\left([\mathrm{M}-\mathrm{H}-146-18]^{-}\right)$was also carried out, and multiple product ions were formed at higher collision energies ( 15 and $20 \mathrm{eV}$ ); these could be critical ions for determining the structure of aglycones. In short, these compounds were definitively or tentatively identified from OHPLE according to the particular fragmentation patterns. The other compounds, including flavones, flavone $O$-glycosides, isoflavones, and isoflavone $O$-glycosides were also characterized. The detailed description can be found in the supplemental data.

\subsection{Quantitative Analysis of OHPL and OHPLE}

Quantitative analysis was performed on the basis of the calibration curves of eight flavone standards by using HPLC detection, as depicted in Table 2. Similar to OHPL, the results suggest that OHPLE was enriched with flavonoids $(151.54 \pm 1.19 \mathrm{mg} / \mathrm{g})$. Compound $\boldsymbol{d}$ apigenin 8 -C-neohesperidoside $(33.63 \pm 0.49 \mathrm{mg} / \mathrm{g})$ and compound $\boldsymbol{e}$ apigenin 6 - $C$-neohesperidoside $(47.43 \pm 0.18 \mathrm{mg} / \mathrm{g})$ were the dominant $C$-flavones in OHPLE. 
Table 1. Identification of 46 flavonoids from OHPLE by UPLC-ESI-QTOF-MS/MS

\begin{tabular}{|c|c|c|c|c|c|c|c|c|}
\hline Peak & RT (min) & $\lambda_{\max }(\mathrm{nm})$ & {$[\mathrm{M}-\mathrm{H}]^{-}(\mathrm{m} / \mathrm{z})$} & Formula & ppm & $\mathrm{MS}^{2}$ fragment ions $(\mathrm{m} / \mathrm{z})$ & Identification & Ref. \\
\hline \multicolumn{9}{|c|}{ Flavone $C$-glycosides } \\
\hline 2 & 4.7 & 270,352 & 593.1523 & C27H30O15 & -1.97 & $447[\mathrm{M}-\mathrm{H}-\mathrm{Rha}]^{-}, 357\left[^{0,3} \mathrm{X}\right]^{-}, 327\left[^{0,2} \mathrm{X}\right]^{-}, 285,163,133$ & luteolin 6-C-neohesperidoside * & {$[15,16]$} \\
\hline 3 & 5.1 & 270,350 & 447.0936 & $\mathrm{C} 21 \mathrm{H} 20 \mathrm{O} 11$ & -1.31 & $357\left[\left[^{0,3} \mathrm{X}\right]^{-}, 327\left[{ }^{0,2} \mathrm{X}\right]^{-}, 285,175,163,133\right.$ & luteolin 6-C-glucoside * & [17] \\
\hline 4 & 5.2 & 268,350 & 447.0939 & $\mathrm{C} 21 \mathrm{H} 20 \mathrm{O} 11$ & -1.90 & $357\left[^{0,3} \mathrm{X}\right]^{-}, 327\left[\left[^{0,2} \mathrm{X}\right]^{-}, 285,175,163,133\right.$ & luteolin 8-C-glucoside * & {$[17,18]$} \\
\hline 5 & 5.4 & 270,352 & 593.1527 & C27H30O15 & -2.03 & $447[\mathrm{M}-\mathrm{H}-\mathrm{Rha}]^{-}, 357\left[^{0,3} \mathrm{X}\right]^{-}, 327\left[^{0,2} \mathrm{X}\right]^{-}, 285 ; 163 ; 133$ & luteolin 8-C-neohesperidoside ${ }^{\ddagger}$ & \\
\hline 6 & 5.8 & 269,340 & 577.1573 & $\mathrm{C} 27 \mathrm{H} 30 \mathrm{O} 14$ & -1.56 & $431[\mathrm{M}-\mathrm{H}-\mathrm{Rha}]^{-}, 341\left[^{0,3} \mathrm{X}\right]^{-}, 311\left[^{0,2} \mathrm{X}\right]^{-}, 283,269,175,131,117$ & apigenin 8-C-neohesperidoside * & [19] \\
\hline 7 & 6.4 & 270,340 & 577.1574 & $\mathrm{C} 27 \mathrm{H} 30 \mathrm{O} 14$ & -1.74 & $431[\mathrm{M}-\mathrm{H}-\mathrm{Rha}]^{-}, 341\left[\left[^{0,3} \mathrm{X}\right]^{-}, 311\left[^{0,2} \mathrm{X}\right]^{-}, 283,269,175,131,117\right.$ & apigenin 6-C-neohesperidoside * & [20] \\
\hline 8 & 6.7 & 271,340 & 593.1526 & $\mathrm{C} 27 \mathrm{H} 30 \mathrm{O} 15$ & -2.18 & $431[\mathrm{M}-\mathrm{H}-\mathrm{Glc}]^{-}, 341\left[^{0,3} \mathrm{X}^{-}, 311\left[^{0,2} \mathrm{X}\right]^{-}, 283,269,175,131,117\right.$ & apigenin 8-C-diglucoside $\ddagger$ & \\
\hline 9 & 6.8 & 270,338 & 431.0981 & $\mathrm{C} 21 \mathrm{H} 20 \mathrm{O} 10$ & 0.34 & $341\left[\left[^{0,3} \mathrm{X}\right]^{-}, 311\left[^{0,2} \mathrm{X}\right]^{-}, 283,269,117\right.$ & apigenin 6-C-glucoside * & {$[21,22]$} \\
\hline 15 & 9.4 & 1 & 433.1141 & $\mathrm{C} 21 \mathrm{H} 22 \mathrm{O} 10$ & 0.13 & $343\left[\left[^{0,3} \mathrm{X}\right]^{-}, 271\right.$ & naringenin $C$-glucoside $\ddagger$ & \\
\hline \multicolumn{9}{|c|}{ Flavones } \\
\hline 18 & 10.4 & 287 & 271.0613 & $\mathrm{C} 15 \mathrm{H} 12 \mathrm{O} 5$ & -1.01 & 1 & naringenin isomer $\ddagger$ & \\
\hline 19 & 10.7 & 286 & 287.0565 & $\mathrm{C} 15 \mathrm{H} 12 \mathrm{O} 6$ & -1.7 & $151\left[\left[^{1,3} \mathrm{~A}\right]^{-}, 135\left[\left[^{1,3} \mathrm{~B}\right]^{-}\right.\right.$ & aromadendrin $\ddagger$ & [12] \\
\hline 26 & 14.1 & 266,323 & 285.0408 & C15H10O6 & -1.49 & $151\left[\left[^{1,3} \mathrm{~A}\right]^{-}, 133\left[\left[^{1,3} \mathrm{~B}\right]^{-}\right.\right.$ & kaempferol ${ }^{\ddagger}$ & [12] \\
\hline 27 & 14.4 & 288,324 & 287.0563 & $\mathrm{C} 15 \mathrm{H} 12 \mathrm{O} 6$ & -0.72 & $151\left[\left[^{1,3} \mathrm{~A}\right]^{-}, 135\left[^{1,3} \mathrm{~B}\right]^{-}\right.$ & eriodictyol $\ddagger$ & \\
\hline 31 & 16.1 & 269,328 & 283.0613 & $\mathrm{C} 16 \mathrm{H} 12 \mathrm{O} 5$ & 0.17 & $151\left[\left[^{1,3} \mathrm{~A}\right]^{-}, 131\left[^{1,3} \mathrm{~B}\right]^{-}\right.$ & acacetin isomer $\ddagger$ & \\
\hline 32 & 16.7 & 266,335 & 285.0409 & C15H10O6 & -1.48 & $151\left[^{1,3} \mathrm{~A}\right]^{-}, 133\left[^{1,3} \mathrm{~B}\right]^{-}$ & luteolin & \\
\hline 35 & 20.2 & 288 & 271.0609 & $\mathrm{C} 15 \mathrm{H} 12 \mathrm{O} 5$ & 0.93 & $151\left[\left[^{1,3} \mathrm{~A}\right]^{-}, 119\left[^{1,3} \mathrm{~B}\right]^{-}\right.$ & naringenin $\ddagger$ & [12] \\
\hline 37 & 22.1 & 270,330 & 283.0609 & $\mathrm{C} 16 \mathrm{H} 12 \mathrm{O} 5$ & -2.21 & $151\left[^{1,3} \mathrm{~A}\right]^{-}, 131\left[^{1,3} \mathrm{~B}\right]^{-}$ & acacetin $\ddagger$ & \\
\hline 38 & 22.3 & 263 & 269.0459 & $\mathrm{C} 15 \mathrm{H} 10 \mathrm{O} 5$ & -1.43 & $151\left[\left[^{1,3} \mathrm{~A}\right]^{-}, 117\left[\left[^{1,3} \mathrm{~B}\right]^{-}\right.\right.$ & apigenin $\ddagger$ & [12] \\
\hline 43 & 23.5 & 266 & 299.0566 & $\mathrm{C} 16 \mathrm{H} 12 \mathrm{O} 6$ & -1.24 & $151\left[\left[^{1,3} \mathrm{~A}\right]^{-}, 147\left[{ }^{1,3} \mathrm{~B}\right]^{-}\right.$ & diosmetin $\ddagger$ & \\
\hline 44 & 23.7 & 1 & 299.0568 & $\mathrm{C} 16 \mathrm{H} 12 \mathrm{O} 6$ & -1.93 & 1 & diosmetin isomer $\ddagger$ & \\
\hline \multicolumn{9}{|c|}{ Flavone $O$-glycosides } \\
\hline 1 & 3.2 & 287 & 595.1675 & $\mathrm{C} 27 \mathrm{H} 32 \mathrm{O} 15$ & -1.42 & $287\left[^{\left[M-H-r^{2} u t i n o s i d e\right.}\right]^{-}, 241,213,151,117$ & aromadendrin 3-O-rutinoside ${ }^{\ddagger}$ & \\
\hline 10 & 7.1 & 267,338 & 577.1571 & $\mathrm{C} 27 \mathrm{H} 30 \mathrm{O} 14$ & -2.56 & 431[M-H-Rha $]^{-}, 269[\mathrm{M}-\mathrm{H}-\text { rutinoside }]^{-}, 151,117$ & apigenin $O$ - rutinoside ${ }^{\ddagger}$ & \\
\hline 12 & 8.4 & 1 & 579.2093 & $\mathrm{C} 28 \mathrm{H} 36 \mathrm{O} 13$ & -1.65 & 417 [M-H-Glc] ${ }^{-}, 271$ [M-H-Glc-Rha] ${ }^{-}, 151,119$ & naringenin $O$-rha-glucoside $\ddagger$ & \\
\hline 16 & 9.5 & 260 & ${ }^{\#} 433.1124$ & $\mathrm{C} 21 \mathrm{H} 20 \mathrm{O} 10$ & 1.09 & $271[\mathrm{M}+\mathrm{H}-\mathrm{Glc}]^{+}, 153,119$ & apigenin 7-O-glucoside ${ }^{\ddagger}$ & \\
\hline 17 & 9.7 & 266,348 & 607.1679 & $\mathrm{C} 28 \mathrm{H} 32 \mathrm{O} 15$ & -1.66 & $299\left[\mathrm{M}-\mathrm{H}-\right.$ rutinoside $^{-}, 151,147$ & diosmetin 7-O-rutinoside * & [23] \\
\hline 28 & 14.6 & 268,325 & 577.1575 & C27H30O14 & -1.96 & $445\left[\mathrm{M}-\mathrm{H}-\right.$ pentoside $^{-}, 283$ [M-H-pentoside-Glc] ${ }^{-}, 151,131$ & acacetin $O$-glc-pentoside $\ddagger$ & \\
\hline 29 & 14.8 & 269,332 & 591.1713 & $\mathrm{C} 28 \mathrm{H} 32 \mathrm{O} 14$ & 1.13 & $283\left[\mathrm{M}-\mathrm{H}-\right.$ rutinoside $^{-}, 151,131$ & acacetin 7-O-rutinoside * & {$[24,25]$} \\
\hline 30 & 15.2 & 268,325 & 577.1577 & $\mathrm{C} 27 \mathrm{H} 30 \mathrm{O} 14$ & -2.19 & $445\left[\mathrm{M}-\mathrm{H}-\right.$ pentoside $^{-}, 283\left[\mathrm{M}-\mathrm{H}-\right.$ pentoside-Glc $^{-}, 151,131$ & acacetin O-glc-pentoside ${ }^{\ddagger}$ & \\
\hline
\end{tabular}


Table 1. Cont.

\begin{tabular}{|c|c|c|c|c|c|c|c|c|}
\hline Peak & RT (min) & $\lambda_{\max }(\mathrm{nm})$ & {$[\mathbf{M}-\mathbf{H}]^{-}(m / z)$} & Formula & ppm & $\mathrm{MS}^{2}$ fragment ions $(\mathrm{m} / \mathrm{z})$ & Identification & Ref. \\
\hline \multicolumn{9}{|c|}{ Isoflavones } \\
\hline 22 & 12.2 & 259 & 283.0611 & $\mathrm{C} 16 \mathrm{H} 12 \mathrm{O} 5$ & 0.33 & $255[\mathrm{M}-\mathrm{H}-\mathrm{CO}]^{-}, 227[\mathrm{M}-\mathrm{H}-2 \mathrm{CO}]^{-}, 151\left[^{1,3} \mathrm{~A}\right]^{-}, 131\left[^{1,3} \mathrm{~B}\right]^{-}$ & biochanin $\mathrm{A}^{\ddagger}$ & [12] \\
\hline 25 & 13.9 & 258 & 253.0510 & $\mathrm{C} 15 \mathrm{H} 10 \mathrm{O} 4$ & -1.63 & $225[\mathrm{M}-\mathrm{H}-\mathrm{CO}]^{-}, 197[\mathrm{M}-\mathrm{H}-2 \mathrm{CO}]^{-}, 135\left[^{1,3} \mathrm{~A}^{-}, 117\left[^{1,3} \mathrm{~B}\right]^{-}\right.$ & daidzein $\ddagger$ & [12] \\
\hline 36 & 21.4 & 260 & 269.0457 & $\mathrm{C} 15 \mathrm{H} 10 \mathrm{O} 5$ & -0.62 & $241[\mathrm{M}-\mathrm{H}-\mathrm{CO}]^{-}, 213[\mathrm{M}-\mathrm{H}-2 \mathrm{CO}]^{-}, 151\left[^{1,3} \mathrm{~A}\right]^{-}, 117\left[^{1,3} \mathrm{~B}\right]^{-}$ & genistein $\ddagger$ & [12] \\
\hline 45 & 24.2 & 259 & 267.0660 & $\mathrm{C} 16 \mathrm{H} 12 \mathrm{O} 4$ & 0.70 & $239[\mathrm{M}-\mathrm{H}-\mathrm{CO}]^{-}, 211[\mathrm{M}-\mathrm{H}-2 \mathrm{CO}]^{-}, 149\left[^{1,3} \mathrm{~A}\right]^{-}, 117\left[^{1,3} \mathrm{~B}\right]^{-}$ & isoformononetin $\ddagger$ & [12] \\
\hline 46 & 26.2 & 261 & 283.0613 & $\mathrm{C} 16 \mathrm{H} 12 \mathrm{O} 5$ & -0.52 & $255[\mathrm{M}-\mathrm{H}-\mathrm{CO}]^{-}, 227[\mathrm{M}-\mathrm{H}-2 \mathrm{CO}]^{-}, 165\left[^{1,3} \mathrm{~A}^{-}, 117\left[^{1,3} \mathrm{~B}\right]^{-}\right.$ & isoprunetin $\ddagger$ & [12] \\
\hline \multicolumn{9}{|c|}{ Isoflavone $O$ - glycosides } \\
\hline 11 & 8.0 & I & 431.0981 & $\mathrm{C} 21 \mathrm{H} 20 \mathrm{O} 10$ & -2.19 & $269[\mathrm{M}-\mathrm{H}-\mathrm{Glc}]^{-}, 213,151$ & genistein7-O-glucoside ${ }^{\ddagger}$ & \\
\hline 13 & 8.7 & 264,327 & 577.1571 & $\mathrm{C} 27 \mathrm{H} 30 \mathrm{O} 14$ & -2.56 & 431[M-H-Rha] $]^{-}, 269[\mathrm{M}-\mathrm{H}-\text { rutinoside }]^{-}, 241,213,151,117$ & genistein7-O-rutinoside ${ }^{\ddagger}$ & \\
\hline 14 & 9.0 & I & $\#_{593.1867}$ & $\mathrm{C} 28 \mathrm{H} 32 \mathrm{O} 14$ & 0.02 & $285[\mathrm{M}+\mathrm{H}-\text { rutinoside }]^{+}, 229,153$ & biochanin A -O-rutinoside ${ }^{\ddagger}$ & \\
\hline 21 & 11.7 & 265,325 & 577.1572 & C27H30O14 & -1.71 & $\begin{array}{c}445\left[\mathrm{M}-\mathrm{H}-\text { pentoside }^{-}, \text {, 283[M-H-pentoside-Glc }\right]^{-}, 255,227, \\
165,117\end{array}$ & isoprunetin 7-O-glc-pentoside ${ }^{\ddagger}$ & \\
\hline 33 & 17.7 & 261,325 & ${ }^{\#} 447.1290$ & $\mathrm{C} 22 \mathrm{H} 22 \mathrm{O} 10$ & -0.62 & $285[\mathrm{M}+\mathrm{H}-\mathrm{Glc}]^{+}, 257,229,167,119$ & isoprunetin 7-O-glucoside $\ddagger$ & [12] \\
\hline \multicolumn{9}{|c|}{ Prenylflavones and Polymethoxyflavones } \\
\hline 23 & 12.7 & 1 & 339.1247 & $\mathrm{C} 20 \mathrm{H} 20 \mathrm{O} 5$ & -2.20 & 1 & prenylnaringenin $\ddagger$ & \\
\hline 34 & 18.3 & 1 & 355.1196 & $\mathrm{C} 20 \mathrm{H} 20 \mathrm{O} 6$ & 0.37 & I & prenylaromadendrin $\ddagger$ & \\
\hline 20 & 11.1 & 1 & \#375.1446 & $\mathrm{C} 20 \mathrm{H} 22 \mathrm{O} 7$ & -1.81 & $360\left[\mathrm{M}+\mathrm{H}-\mathrm{CH}_{3}\right]^{+}$ & pentamethoxyflavanone ${ }^{\ddagger}$ & \\
\hline 24 & 13.4 & I & \#315.0854 & $\mathrm{C} 17 \mathrm{H} 14 \mathrm{O} 6$ & 2.50 & $300\left[\mathrm{M}+\mathrm{H}-\mathrm{CH}_{3}\right]^{+}, 285\left[\mathrm{M}+\mathrm{H}-2 \mathrm{CH}_{3}\right]^{+}$ & dihydroxyl-dimethoxyflavone ${ }^{\ddagger}$ & \\
\hline 39 & 22.8 & 1 & 297.0778 & $\mathrm{C} 17 \mathrm{H} 14 \mathrm{O} 5$ & -1.79 & $282\left[\mathrm{M}-\mathrm{H}-\mathrm{CH}_{3}\right]^{-}, 267\left[\mathrm{M}-\mathrm{H}-2 \mathrm{CH}_{3}\right]^{-}$ & dimethoxyl-hydroxyflavone ${ }^{\ddagger}$ & \\
\hline 40 & 22.9 & I & 297.0770 & C17H14O5 & -0.59 & $282\left[\mathrm{M}-\mathrm{H}-\mathrm{CH}_{3}\right]^{-}, 267\left[^{\left.\mathrm{M}-\mathrm{H}-2 \mathrm{CH}_{3}\right]^{-}}\right.$ & dimethoxyl-hydroxyflavone $^{\ddagger}$ & \\
\hline 41 & 23.1 & 1 & 373.0926 & $\mathrm{C} 19 \mathrm{H} 18 \mathrm{O} 8$ & 0.99 & $343\left[\mathrm{M}-\mathrm{H}-2 \mathrm{CH}_{3}\right]^{-}$ & tetramethoxyl-dihydroxyflavone ${ }^{\ddagger}$ & \\
\hline 42 & 23.2 & 1 & 373.0925 & $\mathrm{C} 19 \mathrm{H} 18 \mathrm{O} 8$ & 0.97 & $343\left[\mathrm{M}-\mathrm{H}-2 \mathrm{CH}_{3}\right]^{-}$ & tetramethoxyl-dihydroxyflavone $\ddagger$ & \\
\hline
\end{tabular}

* These compounds were isolated by HSCCC-prep-HPLC; ${ }^{\ddagger}$ these compounds were tentatively identified by QTOF-MS; ${ }^{\#}$ these values were obtained in positive mode.

Table 2. Quantitative analysis of the dominant compounds in OHPL and OHPLE (mg/g).

\begin{tabular}{|c|c|c|c|c|c|c|c|c|c|}
\hline & $a$ & $b$ & $c$ & $d$ & $e$ & $f$ & $g$ & $h$ & Total \\
\hline OHPL & $0.81 \pm 0.11$ & $0.51 \pm 0.14$ & $0.36 \pm 0.10$ & $1.26 \pm 0.07$ & $2.23 \pm 0.28$ & $0.57 \pm 0.11$ & $0.94 \pm 0.23$ & $0.86 \pm 0.75$ & $7.53 \pm 0.45$ \\
\hline OHPLE & $12.87 \pm 0.18$ & $7.77 \pm 0.49$ & $6.25 \pm 0.40$ & $33.63 \pm 0.49$ & $47.43 \pm 0.18$ & $5.94 \pm 0.04$ & $13.25 \pm 0.38$ & $24.39 \pm 0.22$ & $151.54 \pm 1.19$ \\
\hline
\end{tabular}




\subsection{OHPLE Alleviated Depression symptoms in CUMS Mice}

As shown in Figure 5A, the SPT index of mice in the model control group was markedly decreased $(p<0.05)$ compared with the normal control group, suggesting that the CUMS mouse model was successfully established. Compared with the model control group, the SPT index of mice in different OHPLE dose groups (low, medium, and high) and the fluoxetine group increased by $20.9 \%$ (low dose), $17.3 \%$ (medium dose), $28.5 \%$ (high dose), and $27.4 \%$, respectively. The increase in the SPT index in the high-dose group was significant $(p<0.05)$.
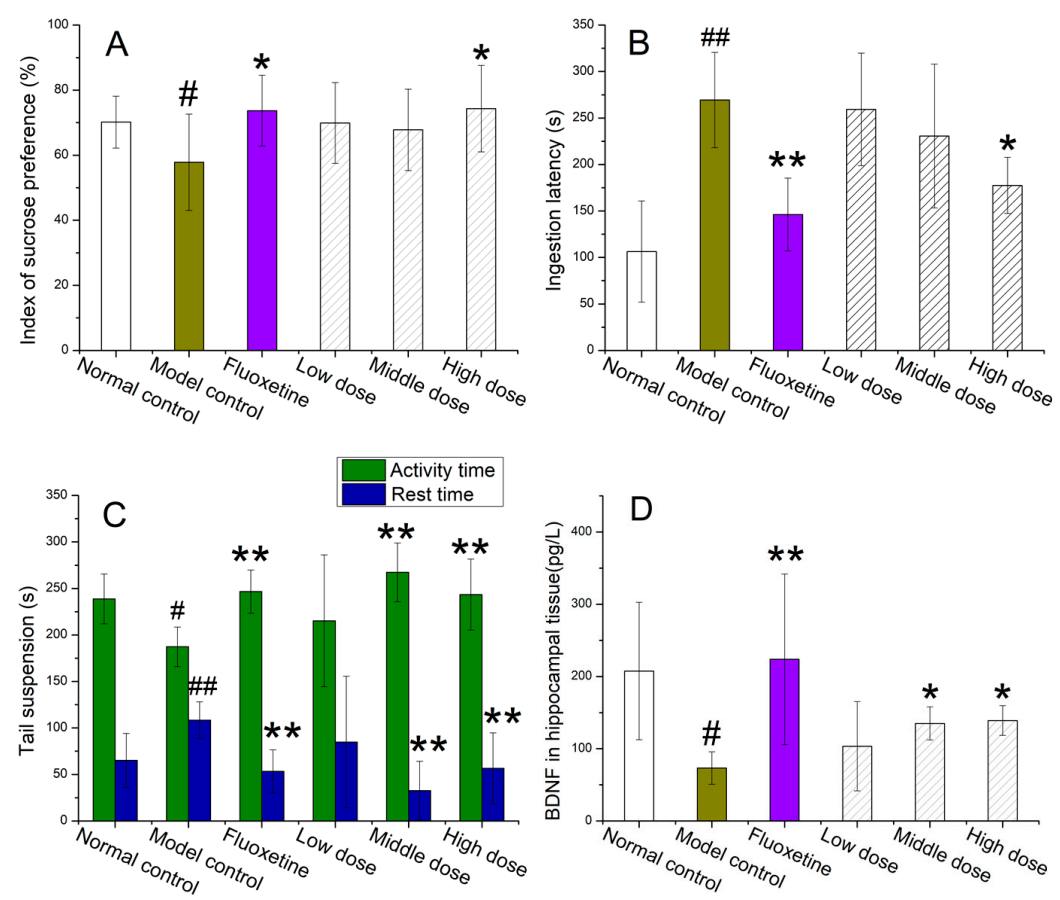

Figure 5. The effects of a series of OHPL extract doses on the behaviors of CUMS mice after treatment. (A) Sucrose preference test, (B) ingestion latency test, (C) tail suspension test and (D) brain-derived neurotrophic factor expression. The values are expressed as the mean $\pm \mathrm{SEM}$. For statistical significance, $\# p<0.05$, \#\# $p<0.01$ compared with the normal control group; ${ }^{*} p<0.05,{ }^{* *} p<0.01$ compared with the model control group.

Figure 5B shows the ILT results, which reveal that the ingestion latency time of mice in the model control group was significantly prolonged compared with that of the mice in the normal control group $(p<0.01)$. The ingestion latency time of mice in the different OHPLE dose groups and the fluoxetine group decreased by $3.7 \%$ (low dose), $15.0 \%$ (medium dose), $34.2 \%$ (high dose), and $45.7 \%$, respectively. The decreases in ILT values in the high-dose OHPLE group and fluoxetine group were significant $(p<0.05, p<0.01)$.

Figure 5C shows the TST results, which show that the activity time of mice in the model control group was significantly reduced $(p<0.05)$ compared with the normal control group, and the rest time was significantly increased $(p<0.01)$. The activity time of mice in different OHPLE dose groups and the fluoxetine group was prolonged by $15.0 \%$ (low dose), $42.8 \%$ (medium dose), $29.9 \%$ (high dose), and 31.6\%, respectively, and the increases in activity time in three groups (medium dose, high dose, and fluoxetine groups) were significant $(p<0.01)$. At the same time, the rest time of the mice decreased by $21.3 \%$ (low dose), $70.3 \%$ (medium dose), $47.2 \%$ (high dose), and 50.9\%, respectively. The decreases in rest time in three groups (medium-dose, high-dose, and fluoxetine groups) were significant $(p<0.01)$.

Figure 5D shows that the BDNF content in the hippocampal tissue of mice in the model control group was significantly reduced $(p<0.01)$ compared with that in the normal control group. The BDNF content in different OHPLE dose groups and the fluoxetine group increased by $41.3 \%$ (low dose), 
$84.1 \%$ (medium dose), $89.5 \%$ (high dose), and 205.2\%, respectively, and the increases in BDNF levels in three groups (medium-dose, high-dose, and fluoxetine groups) were significant $(p<0.05, p<0.01$ ).

The above results show that the high dose of OHPLE significantly increased the index of sucrose preference and reduced the ingestion latency, medium and high doses of OHPLE significantly prolonging the activity time and reducing the rest time. The BDNF expression in the medium-dose and high-dose groups was significantly increased.

\section{Discussion}

Few phytochemical studies of Ormosia genus have been reported. Among these reports, oils [27], quinolizidine alkaloids [28,29], and phenols [30] were proved to exist in this genus. In the current study, the phytochemical investigation and quantitative analysis suggest that flavonoids are the dominant antidepressant components in OHPLE, and it has significant antidepressant effects on CUMS mice.

Antidepressant effects of flavonoids have been performed by many animal model experiments [8,31], and the mechanisms of flavonoids and related analogues are on neurotransmitters, including 5-HT, NA, and DA [32]. C-flavones with monoglycoside or diglycoside possess antidepressant effects [3]. The flavonoid fraction of Cecropia pachystachya was reported to mainly contain luteolin 6-C-glucoside (isoorientin), luteolin 8-C-glucoside (orientin), and apigenin 6-C-glucoside (isovitexin) which could reduce the immobility time in the FST (forced swimming test) at doses of 50 and $100 \mathrm{mg} / \mathrm{kg}$. These results suggested that the flavone $C$-glycoside-enriched fraction exerts antidepressant-like effects [33]. Vitexin (apigenin-8-C-glucoside) significantly increased the mobility time in the FST and TST of mice and exhibited antidepressant activity. The mechanisms of vitexin's antidepressant effects were revealed to be an increase in the catecholamine content in the synaptic cleft, and it interacted with serotonergic $5-\mathrm{HT}_{1 \mathrm{~A}}$; noradrenergic $\alpha_{2}$; and dopaminergic $\mathrm{D}_{1}, \mathrm{D}_{2}$, and $\mathrm{D}_{3}$ receptors [34]. Flavones with an approximated structure, e.g., hydroxy groups, such as luteolin and apigenin, were shown to have good antidepressant capacity through their modulation of monoamine oxidase activity [35]. Oral administration of luteolin (at a dose of $50 \mathrm{mg} / \mathrm{kg}$ ) resulted in antidepressant effects in some behavioral tests (in the FST and TST) [36]. Luteolin raised the levels of monoamine neurotransmitters in the synaptic cleft by directly and indirectly inhibiting serotonin reuptake [37]. Apigenin at doses of 12.5 and $25 \mathrm{mg} / \mathrm{kg}$ displayed antidepressant-like effects by significantly increasing the mobility of mice in the FST. Furthermore, apigenin administration increased mobility in the FST, induced a decrease in DA turnover in the amygdala, and increased DA turnover in the hypothalamus at a dose of $25 \mathrm{mg} / \mathrm{kg}$ [38]. Apigenin also attenuated CMS-induced alterations in serotonin (5-HT) [39]. Moreover, the isoflavones genistein and daidzein resulted in an increased activity time in the FST, indicating an effective antidepressant effect in mice [40]. These data support the results of the antidepressant effect of OHPLE in the current study directly or indirectly.

\section{Materials and Methods}

\subsection{Plant Material and Reagents}

Ormosia henryi Prain leaf (OHPL) samples (No. 20180809) were obtained from Hunan Linuo Biological Pharmaceutical Co., Ltd. (Chenzhou, China) and identified by Zhi Wang (College of Pharmacy, Hunan University of Traditional Chinese Medicine). Organic reagents, including $n$-butanol, methyl tert-butyl ether (MTBE) ethanol, acetic acid, and hydrochloric acid were used for sample preparation and isolation. Analytical-grade acetonitrile, methanol, and formic acid (Sinopharm Chemical Reagent Co., Ltd., Shanghai, China) were used for HPLC and UPLC-ESI-QTOF-MS/MS analysis. Ultra-pure water was obtained from a hyperpure water purifier (Barnstead Easy Pure II, Merck chemical technology, Co. Ltd., Shanghai, China). 


\subsection{Extraction and Isolation of Dominant Compounds}

For extract preparation, $2.0 \mathrm{~kg}$ of dried OHPL was ultrasonically extracted with $30.0 \mathrm{~L}$ of $70 \%$ ethanol for $30 \mathrm{~min}$ in triplicate. The filtered solutions were gathered and concentrated by a rotary evaporator (R1001, Zituo instrument equipment Co., Ltd., Zhengzhou, China) under reduced pressure at $55{ }^{\circ} \mathrm{C}$ until there was no ethanol odor. The concentrate was obtained and then extracted by petroleum ether until the ether layer was colorless. Then, the $\mathrm{pH}$ of the OHPL concentrate was adjusted to 3 by adding hydrochloric acid. About $6.0 \mathrm{~L}$ of OHPL concentrate was passed through a column containing $1000 \mathrm{~mL}$ of $\mathrm{AB}-8$ macroporous resin at $2-3 \mathrm{BV} / \mathrm{h}$ and left to stand for $30 \mathrm{~min}$. This resin was washed by ultrapure water (about $10 \mathrm{BV}$ ) and then eluted with $70 \%$ ethanol at a flow speed of $2-3 \mathrm{BV} / \mathrm{h}$. The $70 \%$ ethanol eluent was collected and concentrated by a rotary evaporator under reduced pressure at $55^{\circ} \mathrm{C}$ until there was no smell of ethanol. It was dried under vacuum, and a freeze-drying apparatus (MODULYOD-230, Thermo Fisher Scientific, Waltham, MA, USA) was used to obtain OHPLE. The weight of OHPLE was $50.15 \mathrm{~g}$, and it was prepared for subsequent HSCCC separation and antidepressant experiments.

HSCCC (Model TBE 300A, Tauto Biotechnique Co., Ltd., Shanghai, China) [41] was used for the purification of OHPLE. Optimal conditions were determined on the basis of values in the literature $[42,43]$ and the properties of these compounds. The optimal conditions were determined to be a rotation rate of $850 \mathrm{rpm}$, mobile phase flow rate of $2.0 \mathrm{~mL} / \mathrm{min}$, multilayer-coiled column temperature of $20^{\circ} \mathrm{C}$, and detection wavelength of $340 \mathrm{~nm}$. The solvent system composed of n-butanol-MTBE-ethanol-0.1\% acetic acid (3:1:1:6, $v / v)$ which produced good $K$-values for the target compounds and was selected as the separation system in the HSCCC experiment.

OHPLE (250 mg) was dissolved in the lower phase $(20 \mathrm{~mL})$ for HSCCC separation, and the same procedure was repeated 20 times (total OHPLE mass of $5.0 \mathrm{~g}$ ). As illustrated in Figure 6, six fractions from OHPLE (M1, 162-193 min; M2, 204-226 min; M3, 238-261 min; M4, 278-293 min; M5, 323-363 min; M6, 426-521 min) were collected and dried individually. Two compounds, M2 (compound 4, $254.1 \mathrm{mg}$ ) and M3 (compound 5, $234.4 \mathrm{mg}$ ), were obtained with purities of over $98 \%$ according to HPLC analysis. The other four fractions were not pure and required further purification by prep-HPLC with an LC-8A system [44] and HPCL C18 column $(250 \times 10 \mathrm{~mm}, 5 \mu \mathrm{m})$. These compounds were purified by prep-HPLC using a solvent system of acetonitrile and $0.1 \%$ acetic acid in water. The flow rate was $6.0 \mathrm{~mL} / \mathrm{min}$, and the process was monitored at a $340 \mathrm{~nm}$ wavelength. The compounds were separated by prep-HPLC with purities of over $98 \%$. M1 contained compound 1 (12.3 mg), M4 contained compound 7 (6.9 mg), M5 contained compound $2(24.5 \mathrm{mg})$ and $3(31.6 \mathrm{mg})$, and M6 contained compounds $6(11.2 \mathrm{mg})$ and $8(14.1 \mathrm{mg})$.

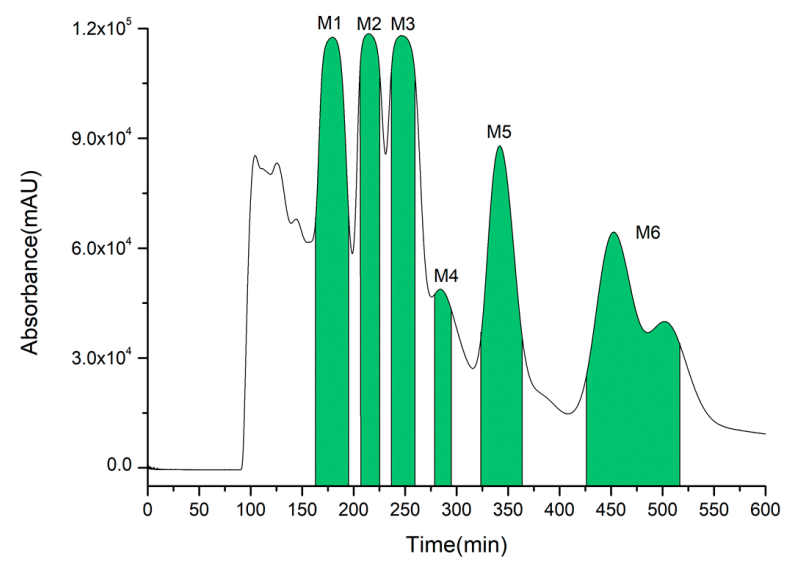

Figure 6. HSCCC chromatogram of OHPLE. Solvent system: $n$-butanol-MTBE-ethanol- $0.1 \%$ acetic acid $(3: 1: 1: 6, v / v)$. The detection wavelength was $340 \mathrm{~nm}$. Sample loading was $250 \mathrm{mg}$ in $20 \mathrm{~mL}$ of the lower phase. The rotation speed was $850 \mathrm{rpm}$. The temperature of the separation columns was maintained at $20^{\circ} \mathrm{C}$, and the flow rate of the mobile phase was $2.0 \mathrm{~mL} / \mathrm{min}$. 


\subsection{UPLC-ESI-QTOF-MS/MS for Phytochemical Analysis}

An Agilent 1290 HPLC system (Agilent Technologies, Palo Alto, CA, USA) with an Agilent 6530 QTOF-MS mass spectrometer was employed for the phytochemical analysis of OHPLE [45]. Matrix separation was performed using an XAqua C18 column $(2.1 \times 150 \mathrm{~mm}, 5 \mu \mathrm{m}$, Agilent Technologies, Acchrom Technologies Co., Ltd., Beijing, China) at a constant temperature $\left(30^{\circ} \mathrm{C}\right)$ and detected at $340 \mathrm{~nm}$. Deionized water ( $0.1 \%$ formic acid, A) and acetonitrile (B) were selected as the solvent system with an optimized gradient elution procedure $(0 \sim 20 \mathrm{~min}, 10 \sim 90 \% \mathrm{~B})$ at a flow rate of $0.3 \mathrm{~mL} / \mathrm{min}$. The injection volume was $2 \mu \mathrm{L}(1.0 \mathrm{mg} / \mathrm{mL})$. The parameters of the MS system were a capillary voltage of $3.5 \mathrm{kV}$ for negative mode, a nebulizer pressure of $50 \mathrm{psi}$, and a nozzle voltage of $1.0 \mathrm{kV}$. The drying gas flow rate was $6 \mathrm{~L} / \mathrm{min}$, the sheath gas temperature was $350{ }^{\circ} \mathrm{C}$ with a flow rate of $11 \mathrm{~L} / \mathrm{min}$, the skimmer voltage was $65 \mathrm{~V}$, OCT1 RF Vpp was $750 \mathrm{~V}$, and the fragmentor voltage was $135 \mathrm{~V}$. The mass data were acquired in negative and positive mode and ranged from $\mathrm{m} / \mathrm{z} 100$ to $1000 \mathrm{Da}$. The typical MS ${ }^{2}$ fragment ions of the isolated compounds were obtained by multiple collision energies, which varied from 5 to $40 \mathrm{eV}$. Mass Hunter Qualitative Analysis B.08.00 was employed for the data analysis.

\subsection{Quantitation of Isolated Compounds}

The quantitation of the eight compounds isolated from OHPLE was performed by a LA-20AT HPLC system (Shimadzu Corporation, Kyoto, Japan) coupled with a GL Sciences WondaSil C18 column $(4.6 \times 250 \mathrm{~mm}, 5 \mu \mathrm{m})$ with a detection wavelength of $340 \mathrm{~nm}$. The column temperature was $30{ }^{\circ} \mathrm{C}$ and the injection volume was $20 \mu \mathrm{L}$, and $0.2 \%$ phosphoric acid (A) and acetonitrile (B) were selected as the solvent system at a flow rate of $1.0 \mathrm{~mL} / \mathrm{min}$ and the following gradient elution procedure: B (15-23\%) for 0-8 $\mathrm{min}, \mathrm{B}(23-30 \%)$ for 8-20 $\mathrm{min}, \mathrm{B}(30-60 \%)$ for $20-25 \mathrm{~min}$, and B (60-15\%) for 25-26 min. Calibration curves were obtained by detecting a series of concentrations of the target compounds. Then, the content of each compound $(\mathrm{mg} / \mathrm{g})$ was calculated.

\subsection{Model of CUMS Mice}

Male ICR mice (weight range of 18.0-22.0 g) were purchased from Hunan Slake Jing-da Experimental Animals Co., Ltd. (Certificate number 43004700048590). In the barrier environment of the Hunan Drug Safety Evaluation and Research Center, the mice were fed at constant temperature $\left(22 \pm 2{ }^{\circ} \mathrm{C}\right)$ with a 12-h light/dark cycle (lights on at 8:00 a.m., lights off at 8:00 p.m.). The laboratory animal use license number is SYXK 2015-06. All experiments and procedures were carried out according to the Regulations of Experimental Animal Administration issued by the State Committee of Science and Technology of China.

In addition to the normal control group of 10 mice, the CUMS model was induced in 60 mice by the following methods: (1) food deprivation for $12 \mathrm{~h}$, (2) water deprivation for $12 \mathrm{~h}$, (3) forced swimming for $10 \mathrm{~min}$, (4) strobe flash for $12 \mathrm{~h}$, (5) noise for $30 \mathrm{~min}$, (6) physical restraint for $12 \mathrm{~h}$ while deprived of food and water (placed in a $50 \mathrm{~mL}$ centrifugal tube with a diameter of $3 \mathrm{~cm}$, length of about $10 \mathrm{~cm}$, and 6-7 vents in the tube wall with a diameter of $0.5 \mathrm{~mm}),(7)$ tilt the cage for $12 \mathrm{~h},(8)$ wet the cage for $12 \mathrm{~h}$, and (9) reversed day and night. These forced experiments were scheduled to take place within a week and repeated for 4 weeks. The normal control mice were fed in cages without disturbance except for cage cleaning.

\subsection{Drug Administration}

The normal control group was treated with distilled water. There were five CUMS mice groups. One group received the positive control drug fluoxetine $(5.2 \mathrm{mg} / \mathrm{kg})$, a widely used antidepressant, which was purchased from Ritual Suzhou Pharmaceutical Co., Ltd. (Suzhou, China). The clinical dose of fluoxetine was $20 \mathrm{mg}$, which was converted into the appropriate dose for mice according to the clinical dose of animals and humans: $20 \mathrm{mg} \times 0.0026 / 0.02 \mathrm{~kg}=2.6 \mathrm{mg} / \mathrm{kg}$. The clinical equivalent dose 
was twice that calculated for mice, namely, $5.2 \mathrm{mg} / \mathrm{kg}$. The other three groups were administered with different doses of OHPLE: a low-dose group $(50.0 \mathrm{mg} / \mathrm{kg} / \mathrm{day})$, medium-dose group (100.0 mg/kg/day), and high-dose group $(150.0 \mathrm{mg} / \mathrm{kg} /$ day $)$. For the model control group, the mice were supplied with the equivalent volume of distilled water instead of the treatments. Each group was treated the same way for 35 consecutive days to complete their corresponding treatments. The route of administration was gavage. After the last administration, the mice were assessed using the sucrose preference test (SPT), ingestion latency test (ILT), and tail suspension test (TST), and BDNF expression was measured. Results of the acute toxicity test did not reveal any toxicity up to an OHPLE dose of $10.0 \mathrm{~g} / \mathrm{kg} /$ day.

\subsection{Behavior Tests}

The SPT was divided into a training period and test period. The first $24 \mathrm{~h}$ was used as the training period to allow the animals free access to two bottles of a $1 \%$ sucrose solution. In the subsequent $24 \mathrm{~h}$, one of the bottles was replaced with pure water. Mice were disallowed water but not food for $8 \mathrm{~h}$ before the test. The SPT was performed at 9:00 a.m. Mice were housed individually and given free access to a bottle of $100 \mathrm{~mL}$ of a $1 \%$ sucrose solution and a bottle of $100 \mathrm{~mL}$ of pure water. After $15 \mathrm{~h}$, the consumption of the sucrose solution and the pure water was calculated (during the test, the positions of the two bottles were swapped to eliminate the influence of location preference). The sucrose preference was calculated by the following formula: sucrose preference $=$ sucrose consumption/(pure water consumption + sucrose consumption) $\times 100 \%$.

The ILT was performed after the SPT. In brief, on the first day, mice were placed in a square box for $10 \mathrm{~min}$ to allow adaptation. Afterward, the mice were deprived of food but not water for $24 \mathrm{~h}$. During the test, a food pellet was placed in the center of the open box, and the mice were put back to access the food pellet (mice were placed in the same position and direction each time). The time between when the mouse was put into the cage and the first time it fed (each time lasted for $5 \mathrm{~min}$ ) was observed and recorded.

The TST was performed after the ILT. In this test, mice were suspended by their tail on a tail suspension device. The head was about $5 \mathrm{~cm}$ from the table so that there was no place for the mice to climb onto or grasp. The activity time and rest time of the mice were recorded within the remaining $4 \mathrm{~min}$. Mice were prevented from seeing one another to prevent mutual interference.

Finally, the tested mice were sacrificed by cervical dislocation. Hippocampal tissues were quickly taken, and the mean BDNF expression of each group was determined by an immunofluorescence technique. In short, hippocampal tissue was homogenized and centrifuged at $1000 \mathrm{rpm}$ for $10 \mathrm{~min}$. Then, the supernatant was taken, and the BDNF content was detected at $540 \mathrm{~nm}$ (Spectra Max i3x multifunctional spectrum, Meigu Molecular Instruments Co., LTD, Shanghai, China) using an Elisa kit (No. 18072, Wuhan Genmei Biotechnology Co. LTD, Wuhan, China).

\subsection{Statistical Analysis}

SPSS (version 16.0) was employed for statistical analysis, and the measurement data were expressed by the mean \pm SEM. The data of all groups were analyzed by a one-way analysis of variance (ANOVA) followed by Dunnett's test in order to detect inter-group differences. $p<0.05$ was considered as statistically significant.

\section{Conclusions}

In this study, the detailed chemical profile and the preliminary antidepressant effect of OHPLE are described for the first time. The results suggest the potential application of OHPLE (rich in flavone $\mathrm{C}$-glycosides) in the field of nutraceuticals and as functional food additives with depression-regulating functions.

Supplementary Materials: Supplementary materials can be found at http://www.mdpi.com/1422-0067/20/14/ 3396/s1. 
Author Contributions: Y.L., Q.T. designed the experiments; S.Z. performed the experiments; Y.H., S.Z., Y.L. carried out data analysis; Y.H. conceived and wrote the manuscript; C.P. supported the plant materials and Z.W. identified the species; Q.T., Y.L. supported funding help for this study.

Funding: This research was supported by the Scientific Research Fund of Hunan Provincial Education Department (18A099, 17A093, 14C0861), the Construct Program of the Key Discipline of Horticulture in Hunan Province (2016XYX004), Hunan Graduate Research and Innovation Project (CX2018B422), and the National Key Laboratory Cultivation Base Construction Project (16KFXM15).

Acknowledgments: We appreciate Yisong Liu for drawing of mice in the graphical abstract.

Conflicts of Interest: The authors do not have any conflict of interest. We also confirm that there are no conflicts of interest with the Hunan Linuo Biological Pharmaceutical Co. LTD.

$\begin{array}{ll}\text { Abbreviations } & \\ \text { OHPL } & \text { Ormosia henryi Prain leaves } \\ \text { OHPLE } & \text { Ormosia henryi Prain leaf ethanol extract } \\ \text { CUMS } & \text { chronic unpredictable mild stressed } \\ \text { SPT } & \text { sucrose preference test } \\ \text { ILT } & \text { ingestion latency test } \\ \text { TST } & \text { tail suspension test } \\ \text { BDNF } & \text { brain-derived neurotrophic factor } \\ \text { HSCCC } & \text { high-speed counter-current chromatography } \\ \text { prep-HPLC } & \text { preparative high-performance liquid chromatography } \\ & \text { ultra-performance liquid chromatography/electrospray ionization quadrupole } \\ \text { UPLC-ESI-QTOF-MS/MS } & \text { time-of-flight mass spectrometry }\end{array}$

\section{References}

1. O'Keane, V.; Frodl, T.; Dinan, T.G. A review of atypical depression in relation to the course of depression and changes in HPA axis organization. Psychoneuroendocrinology 2012, 37, 1589-1599. [CrossRef] [PubMed]

2. Frandsen, J.R.; Narayanasamy, P. Neuroprotection through flavonoid: Enhancement of the glyoxalase pathway. Redox Biol. 2018, 14, 465-473. [CrossRef] [PubMed]

3. Guan, L.P.; Liu, B.Y. Antidepressant-like effects and mechanisms of flavonoids and related analogues. Eur. J. Med. Chem. 2016, 121, 47-57. [CrossRef] [PubMed]

4. Rakofsky, J.J.; Holtzheimer, P.E.; Nemeroff, C.B. Emerging targets for antidepressant therapies. Curr. Opin. Chem. Biol. 2009, 13, 291-302. [CrossRef] [PubMed]

5. Lee, B.; Sur, B.; Yeom, M.; Shim, I.; Lee, H.; Hahm, D.H. Effect of berberine on depression- and anxiety-like behaviors and activation of the noradrenergic system induced by development of morphine dependence in rats. Korean J. Physiol. Pharmacol. Off. J. Korean Physiol. Soc. Korean Soc. Pharmacol. 2012, 16, 379-386. [CrossRef] [PubMed]

6. Casilla-Lennon, M.M.; Meltzer-Brody, S.; Steiner, A.Z. The effect of antidepressants on fertility. Am. J. Obstet. Gynecol. 2016, 215, 314.e1-314.e5. [CrossRef] [PubMed]

7. Berrocoso, E.; Sanchez-Blazquez, P.; Garzon, J.; Mico, J.A. Opiates as antidepressants. Curr. Pharm. Des. 2009, 15, 1612-1622. [CrossRef]

8. Khan, H.; Perviz, S.; Sureda, A.; Nabavi, S.M.; Tejada, S. Current standing of plant derived flavonoids as an antidepressant. Food Chem. Toxicol. Int. J. Publ. Br. Ind. Biol. Res. Assoc. 2018, 119, 176-188. [CrossRef]

9. Sathyanarayana Rao, T.S.; Yeragani, V.K. Hypertensive crisis and cheese. Indian J. Psychiatry 2009, 51, 65-66.

10. Papakostas, G.I. Tolerability of modern antidepressants. J. Clin. Psychiatry 2008, 69 (Suppl. E1), 8-13.

11. Bahramsoltani, R.; Farzaei, M.H.; Farahani, M.S.; Rahimi, R. Phytochemical constituents as future antidepressants: A comprehensive review. Rev. Neurosci. 2015, 26, 699-719. [CrossRef] [PubMed]

12. Feng, S.X.; Hao, J.; Xu, Z.F.; Chen, T.; Qiu, S.X. Polyprenylated isoflavanone and isoflavonoids from Ormosia henryi and their cytotoxicity and anti-oxidation activity. Fitoterapia 2012, 83, 161-165. [CrossRef] [PubMed]

13. Wang, G.Q. National Chinese Herbal Medicine Compilation; People's Medical Publishing House: Beijing, China, 2005; Volume 4, p. 579. 
14. Guo, K.; Tong, C.; Fu, Q.; Xu, J.; Shi, S.; Xiao, Y. Identification of minor lignans, alkaloids, and phenylpropanoid glycosides in Magnolia officinalis by HPLCDADQTOF-MS/MS. J. Pharm. Biomed. Anal. 2019, 170, 153-160. [CrossRef] [PubMed]

15. Nie, W.; Luo, J.G.; Kong, L.Y. C-glycosylflavonoids from the aerial part of Gypsophila pacifica. Chin. J. Nat. Med. 2010, 8, 250-252. [CrossRef]

16. Prinz, S.; Ringl, A.; Huefner, A.; Pemp, E.; Kopp, B. $4^{\prime \prime \prime}$-Acetylvitexin-2"'-O-rhamnoside, isoorientin, orientin, and 8-methoxykaempferol-3-O-glucoside as markers for the differentiation of Crataegus monogyna and Crataegus pentagyna from Crataegus laevigata (Rosaceae). Chem. Biodivers. 2007, 4, 2920-2931. [CrossRef] [PubMed]

17. Moreira, D.D.; Guimaraes, E.F.; Kaplan, M.A. A C-glucosylflavone from leaves of Piper lhotzkyanum. Phytochemistry 2000, 55, 783-786. [CrossRef]

18. Kato, T.; Morita, Y. C-glycosylflavones with acetyl substitution from Rumex acetosa L. Chem. Pharm. Bull. 1990, 38, 2277-2280. [CrossRef]

19. Zhang, P.C.; Xu, S.X. C-glucoside flavonoids from the leaves of Crataegus pinnatifida Bge. var. major N.E.Br. J. Asian Nat. Prod. Res. 2003, 5, 131-136. [CrossRef]

20. Camargo, L.M.D.; Ferezou, J.P.; Tinoco, L.W.; Kaiser, C.R.; Costa, S.S. Flavonoids from Mimosa xanthocentra (Leguminosae: Mimosoideae) and molecular modeling studies for isovitexin-2"-O-alpha-L-rhamnopyranoside rotamers. Phytochem. Lett. 2012, 5, 427-431. [CrossRef]

21. Fang, J.J.; Ye, G. Flavonoids and xanthones from tripterospermum chinense. Chem. Nat. Compd. 2008, 44, 514-515. [CrossRef]

22. Jayasinghe, U.L.; Balasooriya, B.A.; Bandara, A.G.; Fujimoto, Y. Glycosides from Grewia damine and Filicium decipiens. Nat. Prod. Res. 2004, 18, 499-502. [CrossRef] [PubMed]

23. Lee, S.H. A flavone glycoside from Angelica gigas roots. Nat. Prod. Sci. 2002, 8, 127-128.

24. Zhang, T.T.; Zhou, J.S.; Wang, Q.A. Flavonoids from aerial part of Blupleurum chinense DC. Biochem. Syst. Ecol. 2007, 35, 801-804. [CrossRef]

25. Wang, J.; Xu, J.; Zhang, T.J.; Wu, X.S. Preparation and identification of linarin reference substance from Cirsium setosum. Drugs Clin. 2013, 28, 325-327.

26. Vukics, V.; Ringer, T.; Kery, A.; Bonn, G.K.; Guttman, A. Analysis of heartsease (Viola tricolor L.) flavonoid glycosides by micro-liquid chromatography coupled to multistage mass spectrometry. J. Chromatogr. A 2008, 1206, 11-20. [CrossRef] [PubMed]

27. Peng, W.X.; Zhang, D.Q.; Wu, Y.Q.; Zhang, N.N.; Xu, D.P. Py-GC/MS analysis on medical components of benzene/ethanol extractives of fresh Ormosia henryi leaves in autumn. In Proceedings of the 3rd International Conference on Bioinformatics and Biomedical Engineering, Beijing, China, 11-13 June 2009; Volumes 1-11, pp. 1-4, 1797.

28. Pouny, I.; Batut, M.; Vendier, L.; David, B.; Yi, S.; Sautel, F.; Arimondo, P.B.; Massiot, G. Cytisine-like alkaloids from Ormosia hosiei Hemsl. \& E.H. Wilson. Phytochemistry 2014, 107, 97-101.

29. Van Wyk, B.E. The value of chemosystematics in clarifying relationships in the genistoid tribes of papilionoid legumes. Biochem. Syst. Ecol. 2003, 31, 875-884. [CrossRef]

30. Su, B.N.; Hwang, B.Y.; Chai, H.; Carcache-Blanco, E.J.; Kardono, L.B.S.; Afriastini, J.J.; Riswan, S.; Wild, R.; Laing, N.; Farnsworth, N.R.; et al. Activity-guided fractionation of the leaves of Ormosia sumatrana using a proteasome inhibition assay. J. Nat. Prod. 2004, 67, 1911-1914. [CrossRef]

31. Savelieff, M.G.; Nam, G.; Kang, J.; Lee, H.J.; Lee, M.; Lim, M.H. Development of multifunctional molecules as potential therapeutic candidates for Alzheimer's disease, Parkinson's disease, and amyotrophic lateral sclerosis in the last decade. Chem. Rev. 2019, 119, 1221-1322. [CrossRef]

32. Zhu, J.T.; Choi, R.C.; Chu, G.K.; Cheung, A.W.; Gao, Q.T.; Li, J.; Jiang, Z.Y.; Dong, T.T.; Tsim, K.W. Flavonoids possess neuroprotective effects on cultured pheochromocytoma PC12 cells: A comparison of different flavonoids in activating estrogenic effect and in preventing beta-amyloid-induced cell death. J. Agric. Food Chem. 2007, 55, 2438-2445. [CrossRef] [PubMed]

33. Ortmann, C.F.; Abelaira, H.M.; Reus, G.Z.; Ignacio, Z.M.; Chaves, V.C.; Dos Santos, T.C.; de Carvalho, P.; Carlessi, A.S.; Bruchchen, L.; Danielski, L.G.; et al. LC/QTOF profile and preliminary stability studies of an enriched flavonoid fraction of Cecropia pachystachya trecul leaves with potential antidepressant-like activity. Biomed. Chromatogr. BMC 2017, 31, e3982. [CrossRef] [PubMed] 
34. Can, O.D.; Demir Ozkay, U.; Ucel, U.I. Anti-depressant-like effect of vitexin in BALB/c mice and evidence for the involvement of monoaminergic mechanisms. Eur. J. Pharmacol. 2013, 699, 250-257. [CrossRef] [PubMed]

35. Han, X.H.; Hong, S.S.; Hwang, J.S.; Lee, M.K.; Hwang, B.Y.; Ro, J.S. Monoamine oxidase inhibitory components from Cayratia japonica. Arch. Pharmacal Res. 2007, 30, 13. [CrossRef]

36. Ishisaka, M.; Kakefuda, K.; Yamauchi, M.; Tsuruma, K.; Shimazawa, M.; Tsuruta, A.; Hara, H. Shows an antidepressant-like effect via suppressing endoplasmic reticulum stress. Biol. Pharm. Bull. 2011, 34, 1481-1486. [CrossRef]

37. Zhu, S.; Lei, S.; Zhou, S.; Jin, L.; Zeng, S.; Jiang, H.; Zhou, H. Luteolin shows antidepressant-like effect by inhibiting and downregulating plasma membrane monoamine transporter (PMAT, Slc29a4). J. Funct. Foods 2019, 54, 440-448. [CrossRef]

38. Nakazawa, T.; Yasuda, T.; Ueda, J.; Ohsawa, K. Antidepressant-like effects of apigenin and 2,4,5-trimethoxycinnamic acid from Perilla frutescens in the forced swimming test. Biol. Pharm. Bull. 2003, 26, 474-480. [CrossRef]

39. Yi, L.T.; Li, J.M.; Li, Y.C.; Pan, Y.; Xu, Q.; Kong, L.D. Antidepressant-like behavioral and neurochemical effects of the citrus-associated chemical apigenin. Life Sci. 2008, 82, 741-751. [CrossRef]

40. Mori-Okamoto, J.; Otawara-Hamamoto, Y.; Yamato, H.; Yoshimura, H. Pomegranate extract improves a depressive state and bone properties in menopausal syndrome model ovariectomized mice. J. Ethnopharmacol. 2004, 92, 93-101. [CrossRef]

41. He, Y.; Zhu, S.; Wu, C.; Lu, Y.; Tang, Q. Bioactivity-guided separation of potential d dopamine receptor antagonists from aurantii fructus based on molecular docking combined with high-speed counter-current chromatography. Molecules 2018, 23, 3135. [CrossRef]

42. Cicek, S.S.; Schwaiger, S.; Ellmerer, E.P.; Stuppner, H. Development of a fast and convenient method for the isolation of triterpene saponins from Actaea racemosa by high-speed countercurrent chromatography coupled with evaporative light scattering detection. Planta Med. 2010, 76, 467-473. [CrossRef] [PubMed]

43. Ito, Y.; Ma, Z.; Clary, R.; Powell, J.; Knight, M.; Finn, T.M. Improved partition efficiency with threaded cylindrical column in vortex counter-current chromatography. J. Chromatogr. A 2011, 1218, 4065-4070. [CrossRef] [PubMed]

44. Lu, Y.; He, Y.; Zhu, S.; Zhong, X.; Chen, D.; Liu, Z. New acylglycosides flavones from fuzhuan brick tea and simulation analysis of their bioactive effects. Int. J. Mol. Sci. 2019, 20, 494. [CrossRef] [PubMed]

45. He, Y.; Li, Z.; Wang, W.; Sooranna, S.R.; Shi, Y.; Chen, Y.; Wu, C.; Zeng, J.; Tang, Q.; Xie, H. Chemical profiles and simultaneous quantification of Aurantii fructus by use of HPLC-Q-TOF-MS combined with GC-MS and HPLC methods. Molecules 2018, 23, 2189. [CrossRef] [PubMed] 